\title{
ENVIRONMENTAL PROTECTION IN THE LIGHT OF DISCREPANCY BETWEEN THE NORMATIVE AND THE REALITY
}

\author{
Milan Počuča ${ }^{1}$, Ivan Joksić , Bojana Drasković3
}

*Corresponding author E-mail: pocucabmilan@gmail.com

\begin{tabular}{l}
\hline A R T I C L E I N F O \\
Review Article \\
Received: 11 April 2018 \\
Accepted: 24 April 2018 \\
doi:10.5937/ekoPolj1802697P \\
UDC 502/504:340.134(4/9) \\
\hline
\end{tabular}

Keywords:

environment, pollution, legal methods (legal, social, statistically, systematically et al.). instruments, criminal offense, In addition to the theoretical part of the work an important punishment

JEL: Q01, Q15, Q56, O13, O18

\section{A B S T R A C T}

The work is a synthesis of three important aspects in the approach to the environment, on the basis of which it is possible to meet its normative definition and understanding of the situation in practice. Given this basis it is possible to separate international, general and criminal legal area of its normative regulation. Each of these aspects is equally important in getting to know the area of the environment in our country. Hence, it is used in expanding the methodological approach which comprises a number of aspect is the research pertinent to scope and dynamics of criminal acts against the environment in the country. The results are tabulated on the basis of which conclusions are derived as well as suggestions de le ferenda. Timeframe of the research covers the period 2011-2015. year and is based on information contained in the bulletins RSO. We believe that the five-year period in determining the oscillating trends in the field of criminal law protection of the environment provides sufficient referral. In the final part of the paper, a detailed analysis of material is presented as well as a critical review of the presence of inconsistency between the normative and the real situation in the field of environmental protection.

(C) 2018 EA. All rights reserved.

\section{Introduction}

The environment makes an integral part of everyday life for people worldwide. The proper attitude of the international community, as well as each individual country depends on its level of protection. The legal position of the environment involves a wide range of different levels of regulation. This refers to the applicable international

1 Milan Počuča, PhD, Full professor, Faculty of Law for Commerce and Judiciary in Novi Sad, Geri Karolja Street no. 1, Novi Sad 21 000, Serbia, E-mail: pocucabmilan@gmail.com

2 Ivan Joksić, PhD, Associate professor, Faculty of Law for Commerce and Judiciary in Novi Sad, Geri Karolja Street no. 1, Novi Sad 21 000, Serbia, E-mail: ijoksic@hotmail.rs

3 Bojana Drašković, Associate professor, Faculty for construction menagement,Cara Dušana Street, no.62-64, Belgrad,11000 Serbia, E-mail: bodraskovic@gmail.com

http://ea.bg.ac.rs 
legal instruments and national legislation in this area. The fact is that the legal setting has a very jagged system of regulations governing the various aspects of its legal framework. Any attempt to classify them by nature is characterized by two main areas of normative regulation of environmental protection, one of which makes general legal and other criminal justice aspect of protection. Both of these aspects can complement each other and together participate in building a comprehensive legal mechanisms of their regulation. On general level environment is primarily treated as a human right of the third generation. This law was discovered and legally verified in the second half of the last century. Natural and social environment that is conducive to the affirmation of the right to a healthy environment follows the maturing of awareness of the need to provide legal protection from various forms of its pollution. But the initial understanding of the content and framework for environmental protection was based on the current needs of society to stop its pollution. It later evolved with rapid industrialization with the use of so-called dirty technologies. Goods that are produced using modern technology often upset the whole ecosystem, human health and life. Factors that may be affected by environmental pollution include: soil, water, air, flora and fauna that are contained in the lithosphere, pedosphere, hydrosphere, atmosphere, biosphere and technosphere. Because of the particular importance for society, its survival, but also the further development of the system of protection and improvement of the environment is defined as a set of measures and conditions for: preservation and protection of natural and labour created environmental values; protection of people environment from pollution; protection from the influence of damaging and dangerous materials, ionizing and non-ionizing radiation, noise and vibration; protection from destruction and degradation of natural resources, as well as the measures and conditions for the improvement of environmental quality. Each of these factors, together or in conjunction with one or more other factors, may represent objects through which the environment is endangered. In addition to general level of protection it is essential to protect the environment in the area of criminal law. Hence, it is the object of criminal protection of the entire group of criminal offenses. These works are normatively directed toward a clear definition of incriminating zone framed by environment. By adjusting criminal law to these needs legislators have largely used the existing criminal acts frames and entered blanket or referral norms, whose wider purpose lies in the general provisions of the legislation. Ratio legis of such legislation is the fact that criminal law is not able to explicitly include all possible structures, but also all possible damage to the environment at a given time and in a particular area. Therefore, you can not complete the study of all aspects of the environment without reference to the needs and possibilities of its criminal law protection. In this area one can see the presence of clearly expressed discrepancy between the normative and the real situation.

\section{International framework of environment protection}

Simultaneously with the first forms of environmental pollution, which exceeded the previously existing sporadic cases, is recorded in organized attempts its normative regulation. One of the important events in this direction is the organization of the United Nations Conference on the Human Environment held in Stockholm in 1972. In the 
literature, this conference is seen as a key turning point in the direction of improving environmental protection. The Stockholm Declaration states the alarming state of the environment. It points to the need for further monitoring its quality, utilization of resources, the result of pollution on human health, nature, wildlife. Simultaneously, within the United Nations Environment Program (UNEP) is formed, with the aim of further public awareness rising to the growing danger to the mankind due to disbalance of the aco balance, and especially air pollution, water pollution and rational usage of existing natural resources (Kostadinović Krasić, 2002: 302).

Increased interest, and then legal verification, the right to a healthy environment becomes visible with the adoption of a whole range of international legal instruments. These include several key international documents: the First Additional Protocol on the Protection of Victims of International Armed Conflicts (1977), the Convention on the Prohibition of the Military or any other hostile use of techniques that change the environment (1976), the Convention on the Prohibition or Restriction of the Use of Certain a class of conventional weapons that may be considered to cause excessive traumatic effects and to act without distinction as to the objective (1980) and the Third Protocol on prohibitions and restrictions on the use of combustible weapons. These legal documents belong to the International Humanitarian Law Act, in the area of which it sought to regulate the field of environmental protection in relation to the use of various types of weapons produced by pollution. However, due to the use of weapons in war conflicts, a greater and lesser intensity, it is almost impossible that these funds (do not) have negative effects on the environment.

Although a number of legal documents have been adopted, one of the more important ones for environmental protection, the aforementioned Convention on the Prohibition of the Military or any other hostile use of techniques that change the environment from 1976 (Knežević Predić et al., 2007: 589- 592). Article 1 of the Convention states: "Each State Party to this Convention undertakes not to engage in military or any other hostile use of techniques that modify the environment, which have wide, long-term or severe effects as means of destruction, damage or injury any other Member States" (paragraph 1).

The term "techniques that change the environment" includes any technique for change - through uncontrolled manipulation of natural processes - the dynamic, composition or structure of the Earth including its soil, lithosphere, hydrosphere and atmosphere or the cosmos (Article 2 of the Convention). The text of the Convention prescribes certain restrictions on the possibility of using funds that which can result in environmental pollution. Nevertheless, the Convention does not prohibit the use of modification techniques that do not cause destruction, damage or injury on the part of the enemy (Radivojević, Raičević, 2012: 130). Over the past years, a number of legal instruments have been adopted internationally in order to protect the environment from various forms of its endangering. It is important to point to the international legal documents that our country signed, which became part of our internal law. Of importance for the field of environmental protection, we can highlight the following: 
- Decree on the ratification of the International Plant Protection Convention (,Službeni list FNRJ“ međunarodni ugovori, br. 7/55);

- Law on Ratification of the International Convention for the Protection of Birds (,Službeni list SFRJ“, br. 6/73);

- Decree on the ratification of the Convention on wetlands of international importance, in particular as a habitat for birdworm birds (,Službeni list SFRJ“, međunarodni ugovori, br. 9/77);

- Convention on Cooperation for the Protection and Sustainable Use of the Danube River („Službeni list SCG“, međunarodni ugovori, br. 4/03);

- Law on the ratification of the Framework Convention for the Protection and Sustainable Development of the Carpathians („Službeni glasnik RS“, međunarodni ugovori, br. 102/07);

- Convention on combating desertification in countries with severe drought and / or desertification, especially in Africa (,Službeni glasnik RS”, međunarodni ugovori, br. 102/07);

- Law on the Confirmation of the Convention on the Conservation of European Wild Fauna and Flora and Natural Habitats („Službeni glasnik RS”, međunarodni ugovori, br. 102/07);

- Law on the Confirmation of the Kyoto Protocol to the United Nations Framework Convention on Climate Change (,Službeni glasnik RS”, br. 88/07 и 38/09);

- Law on the Confirmation of the Convention on the Environmental Impact Assessment in a Transboundary Context („Službeni glasnik RS”, međunarodni ugovori, br. 102/07);

- Law on Ratification of the Protocol to the Convention on Long-Range Transboundary Air Pollution on Long-Term Financing of the Co-operation Program for Monitoring and Evaluation of Transboundary Transmission of Air Pollutants in the Long Distance Areas in Europe (EMEP) (,Službeni list SFRJ“, međunarodni ugovori, br. 2/87);

- Montreal Protocol on Substances that Deplete the Ozone Layer (,Službeni list SFRJ“, međunarodni ugovori, br. 16/90 i „Službeni list Srbije i Crne gore“, Međunarodni ugovori, br. 24/04);

- The Law on the Confirmation of the Convention on the Availability of Information, Public Participation in Decision-Making and the Right to Legal Protection in Environmental Matters - Aarhuska convention (,Služebeni glasnik RS“, međunarodni ugovori, br. 38/09).

These instruments have universal relevance and represents the basis of the internal environmental protection system in each signatory country. A significant contribution to 
the legal regulation of the environment is given by European countries. In an umbrella European legal instrument, such as the European Convention for the Protection of Human Rights and Fundamental Freedoms of 1950, there is no mention of the right to a healthy environment because at the time of its adoption it was not revealed. Also in subsequent Protocols (1-13), the environment was not subject to legal regulation (,Službeni list SCG - međunarodni ugovori”, br. 9/2003 и 5/2005).

By analyzing important European legal instruments, we can notice a lack of interest in the legal verification of the right to a healthy environment, until the formation of "The coal and steel community", or its transformation into the European Union. Hence the affirmation and development of the right to a healthy environment can be recognized in the legal instruments adopted within the European Union. In the Treaty on the European Union of 1992, signed in Maastricht, special attention is paid to the healthy environment. Chapter XIX, called environment, is a cornerstone of its later detailed regulation in specific legal instruments. Thus, the provision of Article 174 (former Article 130r) provides: Union policy in the field of environmental protection contributes to the achievement of the following objectives:

- Conservation, protection and improvement of the quality of the environment;

- Protection of human health;

- Wise and rational use of natural resources;

- Encouraging measures at the international level to deal with regional or global environmental problems, in particular in the fight against climate change (Lopandić, 2003: 146).

In the field of environmental protection, two legal documents of the European Union are of particular importance. These are: the 2000 Lisbon Strategy (revised 2004) and the 2001 European Union Strategy for Sustainable Development (revised 2006). These documents link the environment with economic and social development (Jelinčić, Đurović, 2009: 20). In individual legal documents adopted at the level of the European Union, certain aspects of environmental protection are considered. This includes the protection of: water, air, soil, human and animal health, plant protection, etc. It explicitly does not mention certain goods that come into the sphere of environmental protection, but specific plans and programs to protect it are identified. This is, for example, the case with the EU Directive 2001/42 / EC on the assessment of the impact of plans and programs on the environment. Its goal is to achieve a high level of environmental protection and contribute to the inclusion of factors important for the environment and the process of preparing and adopting plans and programs in order to promote sustainable development. It can be achieved by ensuring the adoption of appropriate plans and programs where there is a potential for significant environmental impact. This is especially important when there is an objective possibility of creating significant environmental impacts (Prlja et al., 2012: 161-162). 
In its strategic documents, the European Union has particularly emphasized the need for environmental protection, regardless of the area of human activity. The current European Union's Development Strategy (Europe 2020) defines key objectives in the area of sustainable development. They are dedicated to the efficient use of available resources in a way that protects the environment (Ilić et al., 2017: 45).

Although there is a wide variety of European legal instruments, it is not possible to establish a precise definition of the environment. It could be said that there is as much definition of the environment as the authors dealing with her study. A similar situation is in terms of European regulations regulating the environment. Therefore, the valid legal instruments used by the European Union to improve the position of the environment could be divided into two categories: a) as a set of objective, material standards, relating either to the establishment of a limit on the emission of harmful substances or to the prescribing of concrete standards of product or process quality Production; B) as a set of rules relating to different procedures within the framework of environmental management, such as monitoring procedures for air or water pollution, rules relating to the transparency and accessibility of environmental data (Jelinčić, Đurović, 2009: 22).

Making decisions, while respecting potential environmental consequences, is important at different levels, ranging from strategic to operational work. In addition, the types of decisions in which to consider the environmental impact are in the areas of strategic planning and capital infrastructure investments: the construction of certain industries, green buildings, waste management; Eco-design and product development; Operational management - the introduction of green public procurement (Stevanović Čarapina, 2014: 28). They set up areas in which it is necessary to establish legal mechanisms in countering various forms of environmental degradation. This implies the application of principles and principles that have universal validity. An important step in this direction is the definition and application of the precautionary principle on which all EU regulations must be based (Tubić, 2014: 372).

In the European Union's legal instruments, the right to a healthy environment has never been treated as an essential right, but it is working on its development as procedural and participatory law - through the right to participate and the right to legal redress. The Union views the environment beyond national boundaries, treating it as a regional problem (Kostic, 2009: 220). It is necessary to bear in mind the fact that environmental pollution can not be resolved in the national context, since, in the end, the final outcome of the procedural part of the protection is made by the European Court of Human Rights. Thus, among the various applications that the European Court of Human Rights has acted on, due to non-enforcement of the decisions of the domestic courts of the Contracting States, found an application for non-enforcement of decisions protecting the environment (number 36220/97, judgment of 12 July 2005). With this judgment, the Court emphasized the importance of the environment because it applied a milder criterion when it comes to the applicant's obligation to show a legitimate interest, in this case the applicants directly suffered damage from the operation of the thermal power plants so that the application would be taken into consideration. This case could be an incitement to all those affected by the consequences of pollution by large polluters and want to oppose it (Stopić, Zorić, 2009: 26-29). 


\section{General boundaries for environmental protection}

The right to a healthy environment is guaranteed by the Constitution of the Republic of Serbia (Article 74), by prescribing that "everyone has the right to a healthy environment and on a timely and complete notification of its state, but also the obligation to preserve and improve the environment" Official Gazette of the Republic of Serbia “, No. 98/06). In the law of the Republic of Serbia, the first law that sought to regulate environmental protection in a comprehensive manner was enacted in 1991. He is brought to model by Sweden, which is a systemic law

He brought it back in 1969. After the adoption of this law, which regulates environmental protection in a general way, certain measures of its protection could be determined by special laws. At the same time, a number of by-laws were adopted to concretize legal norms (Popov, 2013: 139-140).

Access to environmental protection can not be effective without adapting national legal frameworks to European and international legal standards. In this field, Serbia has done a lot of accepting the obligations that bring with it the process of accession to the European Union. At the legal level, the Stabilization and Association Agreement (SAA) is considered a fundamental legal document establishing the basic level of cooperation between our country and the European Union ("Official Gazette of the Republic of Serbia - International Agreements" No. 83/2008). In this document (Article 111), cooperation is established with the aim of strengthening administrative structures and procedures to ensure strategic planning of environmental issues and coordination between relevant decision makers and focuses on harmonization of Serbian legislation with the EU acquis (Vasiljević, Đurić, 2012: P. 136).

An important aspect of our country's total relations with the European Union belongs to the general trend of increased carbon dioxide concentrations in the air. According to the Intergovernmental Panel on Climate Change (IPCC 2007), the increase in average annual air temperature by 2100 will be 6.40 Celsius degrees, with uneven and unpredictable intensity of rainfall and storm (Stankovic et al, 2016: 861). The announcement of such major changes obliges all EU Member States, including those in the accession phase, to adapt their legal solutions to practical needs. This implies markedly dynamic changes in the field of preservation and environmental protection against quite certain climate variations in the future.

The normative regulation of the environment in our country is based on the applicable Law on Environmental Protection ("Official Gazette of RS", No. 135 / 04-14 / 16). It is a basic legal regulation that is adapted to the needs of our society and the standards that we, through the process of harmonization with the law of the European Union, have to fulfill. This is explicitly emphasized in the clause of Article 1, which stipulates that "this Law regulates an integral environmental protection system that ensures the realization of the human right to life and development in a healthy environment and a balanced relationship of economic development and the environment in the Republic 
of Serbia". An important segment of environmental governance and environment is the conditions and instruments for: a) sustainable management, preservation of the natural balance, integrity, diversity and quality of natural values and conditions for the survival of all living beings; B) prevention, control, reduction and rehabilitation of all forms of pollution of the environment (Article 2). Their specialty is reflected in the fact that they cover different aspects of the environment.

An important part of each law consists of general principles or principles that allow for its inevitable and consistent application. Their content and number are targeted to focus on the specific legislation in general and special legislation. The category of basic principles are: a) the principle of integrity; B) the principle of prevention and precaution; v) the principle of preserving natural values; $g$ ) the principle of sustainable development; d) the principle of the liability of the polluter and his legal successor; F) the "polluter pays" principle; e) the "user pays" principle; (G) the principle of subsidiary liability; Z) the principle of implementing incentive measures; I) the principle of information and public participation; $j$ ) the principle of the protection of the right to a healthy environment and access to justice. Each of the above principles represents a reliable orientation for bodies participating in a proactive and reactive level of environmental protection. This is also due to the fact that the contents of the provisions in the field of international and national regulations, the subject of which the environment is, are summed up in them.

According to the Law on Environmental Protection, sustainable management of natural values and environmental protection is regulated by special laws and other regulations that regulate: assessment of the impact of plans, programs and projects on the environment; Integrated prevention and control of pollution; nature protection; Protection of air, water, land, forests, geological resources; Chemical management; waste management; Ionizing and non-ionizing radiation; Protection against noise and vibration; Control of a major-accident hazards involving dangerous substances; Crossborder trade and trade in wild species (Article 10). Following this kind of legal solution in our country, a whole range of special laws were adopted, which differentiate the different areas of environmental protection. Based on this, the existing environmental protection system has been completed. However, one should take into account the fact that in a variety of regulations, covering different segments of the environment, there is a lack of the principle of common but different responsibilities.

For example, this would be important in considering our country's relationship with the current issue of climate change in the world. In this analysis, in the absence of the principles of common but different responsibilities in national legislation, mechanisms should be considered to create the conditions for the consistent observance of obligations arising from international treaties in which our country only has the status of a member (Todic, 2016: 57-58). 


\section{Criminal law frameworks for environmental protection}

The protection of the environment implies the application of international and national regulations belonging to the so- Environmental legislation. All the more important elements are outlined in them, without which it is unthinkable to regulate the environment. A far more complete way of normative regulation of the environment is not able to fully protect against its violation. To this end, one of the most important issues is to determine the modality of legal responsibility for development and environmental protection. First of all, it is necessary to give a precise answer to the question of who is considered the title of the right to compensation for damage due to environmental damage? The prescribed obligation for the polluter, the environment is protected. But there are also opinions that it can not be a right holder, but it is logical that this is the entity that carries out all this, which is a subject of public law (the Republic, the Province or the local self-government). This concerns the establishment of civil liability for damage to the environment in its totality, including the carers who care about it.

In addition to civil law, the right to a healthy environment also enjoys criminal protection. In this area the past decade can be considered as a decade of major changes in the criminal justice standardization of the environment. Initially treated as a form of human health disorder, which, as a secondary consideration, it always remains, the environment in the Criminal Code of Serbia became a collective protection object ("Official Gazette of the Republic of Serbia", No. 85 / 05-94 / 16). This refers to the situation before the adoption of the new Criminal Code of Serbia in 2005. Then the environment did not have the status of a group protection facility. Criminal acts in which incidents of environmental damage were incriminated were part of a group of criminal offenses against human health. This legal solution in the criminal doctrine has caused dilemmas for decades. The question was whether the environment should be given legal personality in the criminal law (See: Stojanović, 1995: 293-294). The prevailing opinion was that she deserved it, at first by prescribing only certain crimes, and then by her complete independence. One should not ignore the fact that criminal acts against the environment are distinguished by a multidimensional difference (Petrović, 2015: 646).

In the criminal doctrine there are various ways of classification of criminal acts against the environment. In our opinion, the most acceptable division of criminal offenses into four basic groups is that (Čejović, Kulić, 2014: 487-488):

1. General environmental offenses (environmental pollution Article 260 of the Criminal law of Serbia, non-implementation of environmental protection measures Article 261 of the Criminal law of Serbia, illegal construction and putting into operation of facilities and installations that pollute the environment Article 262 of the Criminal law of Serbia, damage to facilities and devices for Environmental protection Article 263 of the Criminal law of Serbia, environmental damage Article 264 of the Criminal law of Serbia, destruction, damage and removal of protected natural goods from abroad Article 265 of the Criminal law of Serbia, violation of the right to information on the state of the environment Article 268 of the Criminal law of Serbia), 
2. Criminal acts related to dangerous substances (introduction of hazardous substances into Serbia and unauthorized processing, disposal and storage of hazardous substances Article 266 of the Criminal law of Serbia, unauthorized construction of nuclear installations Article 267 of the Criminal law of Serbia),

3. Crimes against plant and animal life (killing and torture of animals Article 269 of the Criminal law of Serbia, transfer of contagious diseases to animals and plants Article 270 of the Criminal law of Serbia, indefinite provision of veterinary assistance Article 271 Criminal law of Serbia, production of harmful means for the treatment of animals Article 272 Criminal law of Serbia, Contamination of food and water for feeding or feeding of animals Article 273 of the Criminal law of Serbia, destruction of forests Article 274 of the Criminal law of Serbia, forest theft Article 275 Criminal law of Serbia),

4. Hunting and fishing offenses (illegal hunting Article 276 of the Criminal law of Serbia, illegal fishing Article 277 of the Criminal law of Serbia).

Although a comprehensive list of environmental offenses is not final. The legislator has left off criminal offenses that protect the citizens from noise, so that they are still in the domain of misdemeanor law (Stojanović, 2009: 605).

Favoring one or more offenses at the expense of others is legally impermissible. Nevertheless, in the doctrine of the criminal act, pollution of the environment (Article 260 ) is considered a typical part, so that when considering this group of crimes it always starts from it. The basic form of a criminal offense exists when the offender violates regulations on the protection, conservation and improvement of the environment by polluting air, water or soil in a greater or larger extent. The offense of the criminal offense is consequently determined and consists of a wider catalog of the manner of execution. It is necessary that the actions undertaken result in a criminal offense by violating air, water or land in a greater or larger extent by violating the regulations on protection, preservation and improvement of the environment (paragraph 1). The purpose of this feature is to distinguish this criminal offense from the relevant violations related to the pollution of the human environment (Vučković, 2014: 64). Violation of regulations from secondary legislation regulating the environment, through protection, preservation and promotion, tells us about the accessory role of criminal law in relation to the relevant provisions of administrative legislation (Joksić, 2012: 24-25).

The third and fourth forms exist "if, due to the work referred to in paragraph 1 of this article, destruction of or damage to the animal or plant world of large proportions or environmental pollution has occurred to the extent that the removal of it requires longer time or cost." The possibility is foreseen for the court to impose a suspended sentence and determine the obligation of the perpetrator to take the prescribed measures of protection, preservation and improvement of the environment within a certain period (paragraph 5). 
To the circle of possible executors of this act is belong natural persons and legal entity. However, in practice, legal entities are far more represented due to the fact that they are the most common environmental pollutants. By establishing the criminal liability of legal entities (in 2008) their prosecution has been placed in criminal frameworks. Since a legal entity is managed by a responsible person, it is by their act or omission that the main perpetrator of the offense is polluting the environment.

The strength and effectiveness of legal solutions are recognizable in the field of their application in practice. In order to determine the presence of a particular criminal offense or their group, it is necessary to investigate the scope and dynamics of their execution in a specific time and space. Therefore, we consider a representative number of committed environmental crimes in our country, taking a five-year period. The established spatial and temporal frameworks are considered as reference for determining certain (un) regularities in the execution of these crimes.

Table 1. Review of the number of committed crimes against the environment in the time period $2011-2015$

\begin{tabular}{|c|c|c|c|c|c|}
\hline $\begin{array}{l}\text { Criminal acts against the environment } \\
\text { Head (XXIV) f criminal law of Serbia }\end{array}$ & 2011 $^{1}$ & $2012^{2}$ & $2013^{3}$ & $2014^{4}$ & $2015^{5}$ \\
\hline Environmental pollution & / & / & 2 & / & / \\
\hline Non-implementation of environmental protection measures & 4 & 1 & / & / & 1 \\
\hline $\begin{array}{l}\text { Unlawful construction and commissioning of facilities and } \\
\text { installations that pollute the environment }\end{array}$ & 1 & 1 & / & / & / \\
\hline $\begin{array}{l}\text { Damage to facilities and devices for environmental } \\
\text { protection }\end{array}$ & / & 1 & / & / & 1 \\
\hline Environmental damage & 3 & 6 & 1 & 3 & 3 \\
\hline $\begin{array}{l}\text { Destruction, damage, taking abroad and entering Serbia's } \\
\text { protected natural heritage }\end{array}$ & 2 & 4 & 3 & 4 & 1 \\
\hline $\begin{array}{l}\text { The introduction of hazardous substances into Serbia and the } \\
\text { unauthorized processing, disposal and storage of hazardous } \\
\text { substances }\end{array}$ & 1 & 1 & 1 & / & / \\
\hline Illegal construction of nuclear plants & 1 & 1 & 1 & 1 & 1 \\
\hline $\begin{array}{l}\text { Violation of the right to information about the state of the } \\
\text { environment }\end{array}$ & 1 & / & / & / & / \\
\hline Killing and abusing animals & 27 & 23 & 30 & 25 & 23 \\
\hline Transmission of infectious diseases in animals and plants & 1 & 1 & / & / & 1 \\
\hline Unhealthy provision of veterinary assistance & / & 1 & l & / & / \\
\hline Production of harmful agents for the treatment of animals & 1 & 1 & / & / & / \\
\hline Pollution of food and water for feeding or feeding of animals & / & 1 & / & / & / \\
\hline Devastation of forests & 30 & 36 & 17 & 30 & 34 \\
\hline Forest theft & 287 & 297 & 407 & 488 & 451 \\
\hline Illegal hunting & 25 & 27 & 14 & 18 & 11 \\
\hline Illegal fishing & 68 & 33 & 33 & 21 & 23 \\
\hline Total: & 449 & 430 & 508 & 589 & 549 \\
\hline
\end{tabular}




\begin{tabular}{|c|c|c|c|c|}
\hline $\begin{array}{l}\text { Criminal acts against the environment } \\
\text { Head (XXIV) f criminal law of Serbia }\end{array}$ & $2012^{2}$ & $2013^{3}$ & $2014^{4}$ & $2015^{5}$ \\
\hline 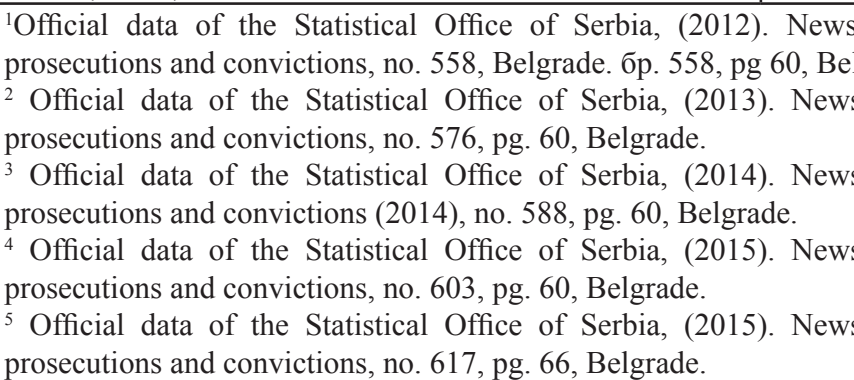 & $\begin{array}{l}\text { grade. } \\
\text { letter - } \\
\text { letter - } \\
\text { letter - } \\
\text { letter - }\end{array}$ & adult off & $\begin{array}{l}\text { enders } \mathrm{H} \\
\text { enders } \mathrm{H} \\
\text { enders } \mathrm{H} \\
\text { enders } \mathrm{H}\end{array}$ & $\begin{array}{l}\text { Handsets, } \\
\text { Handsets, } \\
\text { Handsets, } \\
\text { Handsets, }\end{array}$ \\
\hline
\end{tabular}

The previous table shows the data obtained from the official records of the Statistical Office of Serbia. A five-year period (2011-2015) was taken as a benchmark indicating numerical data of a group of criminal offenses against the environment. Analyzing the obtained data, we can determine the true absence of "interest" among the perpetrators, and partly of the state authorities, in relation to certain criminal acts against the environment. This is primarily a criminal case for environmental pollution whose dark figure is particularly pronounced. In our opinion, this offense is more often done in practice than in the case of official statistics. The fact that sometimes large polluters do not work with the same intensity or extent affect the lesser presence of environmental pollution that had an epidemic situation in the previous period. However, one should not overlook the fact that pollution has not been reduced to that extent, as it makes a slight impression on the public. Previously, the town of Šabac and Pančevo was the predominant area, but other areas were not spared. In them, the number of plant and animal species was decimated by the disproportionate attitude of certain economic entities who injected unfiltered substances into liquid and gaseous state.

If we were to analyze the share of individual crimes in relation to their total number, then it is undoubtedly the criminal act of forest theft. This crime constantly shows an extremely large number in each of the years worked. Given that it is a type of theft, which has specific features, a large number of execution is proportional to the general trend of criminal offenses against property. They participate with a full-scale number in relation to the total number of crimes committed in our country. After this crime, are committing the crimes committed by the devastation of forests, illegal hunting and illegal fishing. Here we can notice a greater oscillation in 2011, when the number of illegal offenses committed was in a large disproportion in relation to all subsequent years. In the rest, we can surely see a large number of crimes listed.

Animal killing and abuse is a significant number of executions resulting from the general state of affairs in society. This implies a general trend of increasing violence among young people, the absence of empathy, the manifestation of sadistic lines of personality in the form of causing harm to animals and others. It is important to emphasize the lack of readiness to report cases of bad relations with animals due to the rooted perception that they are the property of their owners. Hence, for this criminal offense, there is a very 
pronounced disagreement between the number of crimes actually committed and those who received the judicial epilogue. In addition, the literature points to the vague motive of this incrimination, that is, whether it is a matter of inhuman treatment of animals or is a matter of protection because of their value for people and the environment. It is therefore difficult to specify the legal content of this criminal offense (Lazarević, 2011: 827-828).

In the end, it should not be easy to go beyond the fact that certain environmental offenses are not represented in practice or there are no data on their performance. These are criminal offenses: unlawful construction and putting into operation of facilities and plants that pollute the environment, unsafe provision of veterinary assistance and contamination of food and water for feeding or feeding of animals. The reasons for this state of affairs should be found in the fact that these incriminations are closely focused on precisely defined practices that produce negative effects on the environment.

Their dispositions are widely set (so-called standard rubber), which is not the case with other crimes from this group. Hence, in practice they often overlap with other crimes, such as environmental pollution, killing and abuse of animals, etc. In practice, the prosecution authorities should take more account of this because the similar behavior of the perpetrators does not always mean the same criminal offense.

\section{Conclusion}

The right to a healthy environment belongs to the third generation human rights. His discovery and legal verification, within the framework of international instruments, relates to the second half of the 20th century. Since then, we have been recording the process of gradual harmonization of national legislation with international and regional legal instruments. The particularity of this right was reflected in inaccessible frameworks, and therefore the possibilities for its protection. Therefore, we have a situation that certain aspects of environmental protection remain inadequately legally regulated. A clear example confirming this is the protection against noise, which in itself is not a human right, but it is enshrined in the right to a healthy environment as recognized by human right. In this sense, incomplete legal regulation of the environment produces certain disagreements between established normative solutions and their application.

The evolution of the right to a healthy environment can be traced back to the early seventies of the 20th century. An important date in this direction is the Stockholm Conference of 1972, when the need and importance of preserving the environment was narrated. On that occasion, the principle is laid down by which each person has the basic right to freedom, equality and adequate living conditions, in the midst of the quality of which enables life in dignity and well-being and a solemn obligation to stretch and improve this environment for present and future generations.

After this conference, the adoption of a large number of international and European legal instruments was followed, of which the largest number was ratified at the time of the former Yugoslavia. They contain broader legal frameworks in which national environmental regulations should be in place. 
Legal regulation of the environment in most countries in the world is reflected in the sphere of general and criminal legislation. This practically means that the general legal regulations (eg the Law on Environmental Protection) regulate all significant environmental issues. It implies its conceptual determination, the determination of the circle of subjects and their competences, the measures and conditions for environmental protection, the procedure for determining liability for endangering, etc. This kind of normative regulation of the environment is often proved to be insufficient in practice, so it is necessary to use mechanisms of criminal repression. It is about the incriminations for which environmental degradation is qualified as a criminal offense, which entails establishing the criminal responsibility of its perpetrators. In this part, it is of particular importance to introduce the criminal liability of legal persons, thus tracing the way to their prosecution. This is the case with those subjects whose activity, in itself, produces adverse effects on the environment. The study of the volume and dynamics of criminal acts against the environment shows the variable representation of certain criminal offenses of this group. It is necessary to look for the reasons in the present dark number of certain crimes, although it is known that they are almost daily carried out. Especially interesting is the environmental crime (Article 260 of the Criminal law of Serbia), which is not sufficiently represented in the total number of environmental offenses.

\section{Conflict of interests}

The authors declare no conflict of interest.

\section{References}

1. Vasiljevic, M., Djuric, Đ. (2012). Harmonization of regulations of the Republic of Serbia in the field of environmental law in compliance with the EU legislation, Proceedings: Ecology and Law, Institute of Comparative Law, Faculty of Law, University Union, p. 134-149, Belgrade. (In Serbian: Vasiljević, M., Đurić, Đ. (2012). Harmonizacija propisa Republike Srbije u oblasti zaštite životne sredine sa pravom EU, Zbornik radova: Ekologija i pravo, Institut za uporedno pravo, Pravni fakultet Univerziteta Union, str. 134-149, Beograd.

2. Vučković, B. (2014). Environmental criminal procedure law aspect. Law -Theory and Practice, Faculty of Economics and Justice, University Business Academy, 31, p. 59-70, Novi Sad. (In Serbian: Vučković, B. (2014). Zaštita životne sredinekrivičnopravni aspekt. Pravo-teorija i praksa, Pravni fakultet za privredu $i$ pravosude, Univerzitet Privredna akademija, 31, str. 59-70, Novi Sad)

3. Ilić, I. et. al. (2017). Environmental performances of agriculture in the European union countries. Economics of agriculture, Institute for agricultural economics, 64, p. 41-55, Belgrade (In Serbian: Institut za ekonomiku poljoprivrede, 64, str. 41-55, Beograd. 
4. Jelinčić, J., Đurovic, S. (2009). Protecting the environment condition for sustainable development. The Open Society Institute, Center for Applied European Studies, Belgrade. (In Serbian: Jelinčić, J., Đurović, S. (2009). Zaštita životne sredine uslov za održivi razvoj. Fond za otvoreno društvo, Centar za primenjene evropske studije, Beograd)

5. Joksić, I. (2012). Legal protection of the environment in legislation and practice. Proceedings: Ecology and Law, Institute of Comparative Law, Faculty of Law, University Union, p. 20-32, Belgrade. (In Serbian: Joksić, I. (2012). Krivičnopravna zaštita životne sredine u zakonodavstvu i praksi. Zbornik radova: Ekologija i pravo, Institut za uporedno pravo, Pravni fakultet Univerziteta Union, str. 20-32, Beograd.)

6. Kostadinović Krasić, D. (2002). Sustainable development and the development of Yugoslavia. Themes, University of Nis, XXXVII, p. 301-319, Niš. (In Serbian: Kostadinović Krasić, D. (2002). Održivi razvoj i razvoj Jugoslavije. Teme, Univerzitet u Nišu, XXXVII, str. 301-319, Niš)

7. Kostic, M. (2009). Protecting the environment and human rights, Proceedings of the Symposium with international participation - Synergy, Bijeljina. (In Serbian: Kostić, M. (2009). Zaštita životne sredine i ljudska prava, Zbornik radova sa Naučnog skupa sa međunarodnim učešćem - Sinergija, Bijeljina)

8. Knezevic Predic, V. et. al. (2007). Sources of international humanitarian law. Publikum, Belgrade. (In Serbian: Knežević Predić, V. et. al. (2007). Izvori Međunarodnog humanitarnog prava. Publikum, Beograd)

9. Lazarević, Lj. (2011). Comment of the Criminal Code, Law School of Union University, Belgrade. (In Serbian: Lazarević, Lj. (2011). Komentar Krivičnog zakonika, Pravni fakultet Univerziteta Union, Beograd)

10. Lopandić, D. (2003). The founding treaties of the EU - Treaty on European Union and the Treaty of Nice, with amendments to the EU Treaty, the Office for Serbia and Montenegro for European Union, the European Movement in Serbia, the Serbian Ministry for Foreign Economic Relations, Belgrade. (In Serbian: Lopandić, D. (2003). Osnivački ugovori Evropske unije-Ugovor o Evropskoj uniji i Ugovor iz Nice sa amandmanima na Ugovor o EU, Kancelarija za pridruživanje Srbije i Crne Gore Evropskoj uniji, Evropski pokret u Srbiji, Republičko ministarstvo za ekonomske veze sa inostranstvom, Beograd)

11. Local Environmental Action Plan. (2010). Book I: General conditions of local communities, technical reports, Sabac. (In Serbian: Lokalni ekološki akcioni plan. (2010). Knjiga I: Opšti uslovi lokalne zajednice, tehnički izveštaji, Šabac) 
12. Popov, D. (2013). The principles of environmental protection in the documents of the United Nations, the European Union and the Law on Environmental Protection, Proceedings of the Law Faculty in Novi Sad, 47, p. 131-146, Novi Sad. (In Serbian: Popov, D. (2013). Načela zaštite životne sredine u dokumentima Ujedinjenih nacija, Evropske unije $i$ Zakona o zaštiti životne sredine, Zbornik radova Pravnog fakulteta u Novom Sadu, 47, str. 131-146, Novi Sad)

13. Petrovic, Z. et. al. (2015). Ecological protection of agriculture through Serbia's legal regulations and judicial practice. Economics of Agriculture, Institute of Agricultural Economics, 62, pp. 645-660, Belgrade. (In Serbian: Petrović, Z. et. al. (2015). Institut za ekonomiku poljoprivrede, 62, str. 645-660, Beograd)

14. Prlja, D. et al. (2012). Waste Management - International regulations with special reference to the regulations of the European Union, Proceedings: Ecology and Law, Institute of Comparative Law, Faculty of Law, University Union, p.150-166, Belgrade. (In Serbian: Prlja, D. et al. (2012). Upravljanje otpadom - Međunarodni propisi sa posebnim osvrtom na regulativu Evropske unije, Zbornik radova: Ekologija i pravo, Institut za uporedno pravo, Pravni fakultet Univerziteta Union, str. 150-166, Beograd)

15. Radivojevic, Z., Raičević, N. (2012). Environmental protection in international humanitarian law, Yearbook FPS, VI, p. 123-143, Belgrade. (In Serbian: Radivojević, Z., Raičević, N. (2012). Zaštita životne sredine u međunarodnom humanitarnom pravu, Godišnjak FPN, VI, str. 123-143, Beograd)

16. Stankovic, M. et. al. (2016). Ecological importance of innovative electrical devices in the process of anti ambrosia artemisiifolia L. Economics of agriculture, 63, 861-870, Belgrade.

17. Stopić, M., Zoric, J. (2009). The right to a healthy environment in the European Court of Human Rights, Belgrade Center for Human Rights, Belgrade (In Serbian: Pravo na zdravu životnu sredinu u praksi Evropskog suda za ljudska prava, BG Centar za ljudska prava, Beograd)

18. Čarapina Stevanovic, H. et al. (2014). MFA and LCA as analytical instruments in the environmental field, Limes plus, XI, p. 27-41, Belgrade. (In Serbian: Stevanović Čarapina, H. et al. (2014). MFA i LCA kao analitički instrumenti u oblasti životne sredine, Limes plus, XI, str. 27-41, Beograd)

19. Stojanović, Z. (1995). Legal protection of the environment, Legal Life, 44, 291-301, Belgrade. (In Serbian: Stojanović, Z. (1995). Krivičnopravna zaštita životne sredine, Pravni život, 44, 291-301, Beograd)

20. Stojanović, Z. (2009).Comment of the Criminal Code, Official Gazette, Belgrade. (In Serbian: Stojanović, Z. (2009). Komentar Krivičnog zakonika, Službeni glasnik, Beograd) 
21. Stojanovic, P., Zindović, I. (2015). Legal responsibility for the development and protection of the environment, Annals of the Faculty of Law in Belgrade, LXIII, p. 41-57, Belgrade. (In Serbian: Stojanović, P., Zindović, I. (2015). Pravna odgovornost za razvoj i zaštitu životne sredine, Anali Pravnog fakulteta u Beogradu, LXIII, str. 41-57, Beograd)

22. Todic, D. (2016). Paris climate agreement in the light of the objectives and principles of modern policy and environmental law, Megatrend Review, 13, p. 45-62, Belgrade (In Serbian:Todić, D. (2016). Pariski sporazum o klimi u svetlu ciljeva i principa savremene politike i prava životne sredine, Megatrend revija, 13, str. 45-62, Beograd)

23. Tubić, B. (2014). The precautionary principle in international environmental law and international jurisprudence, Proceedings of the Law Faculty in Novi Sad, 48, p. 367-384, Novi Sad. (In Serbian: Tubić, B. (2014). Načelo predostrožnosti u međunarodnom pravu životne sredine $i$ međunarodnoj sudskoj praksi, Zbornik radova Pravnog fakulteta u Novom Sadu, 48, str. $367-$ 384, Novi Sad)

24. Čejović, B. Kulic, B. (2014). Criminal law-general and special part. University Business Academy, Faculty of Economics and Justice, Novi Sad. (In Serbian: Čejović, B., Kulić, B. (2014). Krivično pravo-opšti i posebni deo. Univerzitet Privredna akademija, Pravni fakultet za privredu i pravosuđe, Novi Sad)

\section{Regulations}

25. The Constitution of the Republic of Serbia ( "RS Official Gazette", no. 98/06). (In Serbian: Ustav Republike Srbije (,,Službeni glasnik RS“, br. 98/06))

26. Law on Environmental Protection of the Republic of Serbia ("RS Official Gazette”, no. 135 / 04-14 / 16). (In Serbian: Zakon o zaštiti životne sredine Republike Srbije (,, Službeni glasnik RS“, br. 135/04-14/16))

27. The Criminal Code of the Republic of Serbia ( "RS Official Gazette", no. 85 / 05-94 / 16) (In Serbian: Krivični zakonik Republike Srbije (,,Službeni glasnik $R S$ “, br. 85/05-94/16))

28. Law on liability of legal persons for criminal acts of the Republic of Serbia ( "RS Official Gazette", no. 97/08). (In Serbian: Zakon o odgovornosti pravnih lica za krivična dela Republike Srbije (,, Službeni glasnik RS“, br. 97/08))

\section{Publication of Republican Bureau of Statistics}

29. Official data of the Statistical Office of Serbia, (2012). Newsletter - adult offenders Handsets, prosecutions and convictions, no. 558, Belgrade. (In Serbian: Zvanični podaci Republičkog zavoda za statistiku Srbije, (2012). Bilten - Punoletni učinioci krivičnih dela-Prijave, optuženja i osude, br. 558, Beograd) 
30. Official data of the Statistical Office of Serbia, (2013). Newsletter - adult offenders Handsets, prosecutions and convictions, no. 576, Belgrade. (In Serbian: Zvanični podaci Republičkog zavoda za statistiku Srbije, (2013). Bilten - Punoletni učinioci krivičnih dela-Prijave, optuženja i osude, br. 576, Beograd)

31. Official data of the Statistical Office of Serbia, (2014). Newsletter - adult offenders Handsets, prosecutions and convictions, no. 588, Belgrade. (In Serbian: Zvanični podaci Republičkog zavoda za statistiku Srbije, (2014). Bilten - Punoletni učinioci krivičnih dela-Prijave, optuženja i osude, br. 588, Beograd)

32. Official data of the Statistical Office of Serbia, (2015). Newsletter - adult offenders Handsets, prosecutions and convictions, no. 603, Belgrade. (In Serbian: Zvanični podaci Republičkog zavoda za statistiku Srbije, (2015). Bilten - Punoletni učinioci krivičnih dela-Prijave, optuženja i osude, br. 603, Beograd)

33. Newsletter - adult offenders Handsets, prosecutions and convictions, no. 617, Belgrade. (Official data of the Statistical Office of Serbia, (2016). In Serbian: Zvanični podaci Republičkog zavoda za statistiku Srbije, (2016). Bilten Punoletni učinioci krivičnih dela-Prijave, optuženja i osude, br. 617, Beograd) 